\title{
PROCESSING OF $\mathrm{CO}_{2}$ SAMPLES COLLECTED USING ZEOLITE MOLECULAR SIEVE FOR ${ }^{14} \mathrm{C}$ ANALYSIS AT THE NERC RADIOCARBON FACILITY (EAST KILBRIDE, UK)
}

\author{
M H Garnett ${ }^{1}$ C Murray \\ NERC Radiocarbon Facility, Rankine Avenue, East Kilbride G75 0QF, United Kingdom.
}

\begin{abstract}
Cartridges containing a zeolite molecular sieve are used for the field collection of $\mathrm{CO}_{2}$ from a variety of environments (e.g. atmosphere, soil respiration, evasion from surface waters) for accelerator mass spectrometry (AMS) radiocarbon analysis by the NERC Radiocarbon Facility. Previously, sample $\mathrm{CO}_{2}$ was recovered from the sieves by heating under vacuum prior to cryogenic purification and graphitization. An additional heating and evacuation stage was used to prepare the cartridge for the next sample. We have recently developed an alternative method using heating and purging with nitrogen gas to remove sample $\mathrm{CO}_{2}$ from the molecular sieve. An infrared gas analyzer (IRGA) is used to continuously monitor $\mathrm{CO}_{2}$ content in the purge gas. The preparation of the molecular sieve cartridge for the next use is performed simultaneously and the IRGA reading is used to verify that all sample $\mathrm{CO}_{2}$ has been removed from the sieve, ensuring insignificant carryover of $\mathrm{CO}_{2}$ into the next sample. We present the results of a suite of standards of distinctly different ${ }^{14} \mathrm{C}$ and stable-carbon isotope composition, which we used to confirm the reliability of the new procedure. The new method has considerably reduced the time required to process a single sample from at least $2 \mathrm{hr}$ to less than $40 \mathrm{~min}$, and reduced the minimum sample size by $50 \%$.
\end{abstract}

\section{INTRODUCTION}

A zeolite molecular sieve is a crystalline alumino-silicate with selectivity and adsorption properties that make it particularly useful to trap or purify carbon dioxide (Bol and Harkness 1995). It has been utilized in radiocarbon science from at least the 1960s for sampling atmospheric $\mathrm{CO}_{2}$ (e.g. Godwin and Willis 1964). It is particularly valuable as an alternative to cryogenic methods for purifying $\mathrm{CO}_{2}$ on vacuum systems (e.g. Bauer et al. 1992), facilitating its use in the recent automation of laboratory procedures in the preparation of ${ }^{14} \mathrm{C}$ samples (e.g. Wacker et al. 2010).

At the NERC Radiocarbon Facility (East Kilbride, UK), we use cartridges containing zeolite molecular sieves for the field collection of $\mathrm{CO}_{2}$ from a variety of environments for ${ }^{14} \mathrm{C}$ analysis by accelerator mass spectrometry (AMS). For example, the molecular sieve cartridges (MSCs) have been used with a pump-based sampling system (Hardie et al. 2005) to collect $\mathrm{CO}_{2}$ respired in various environments (e.g. arctic tundra, Hartley et al. 2012; temperate peatlands, Hardie et al. 2009; or evaded from surface waters, Billett et al. 2006, or subsurface pipes, Billett et al. 2012). They have also been deployed as passive samplers, for example, to recover $\mathrm{CO}_{2}$ for ${ }^{14} \mathrm{C}$ analysis from the atmosphere (Garnett and Hartley 2010), the permanently waterlogged layers of peats (using hydrophobic filters; Garnett and Hardie 2009), or surface emissions of soils (Garnett et al. 2009).

Hardie et al. (2005) describe the methods we previously used for processing molecular sieve samples, involving heating under vacuum to recover sample $\mathrm{CO}_{2}$ from the sieve prior to cryogenic purification and graphitization (based on earlier methods described by Bol and Harkness 1995). An additional heating and evacuation stage was used to prepare the cartridge for the next sample. We have recently developed a more efficient method to process $\mathrm{CO}_{2}$ samples collected using a molecular sieve and to prepare the cartridges for next use. Here, we describe the new method to process samples collected using MSCs and demonstrate the reliability of the method with the results of a suite of standards.

${ }^{1}$ Corresponding author. Email: M.Garnett@nercrcl.gla.ac.uk.

C 2013 by the Arizona Board of Regents on behalf of the University of Arizona Proceedings of the 21 st International Radiocarbon Conference edited by A J T Jull \& C Hatté RADIOCARBON, Vol 55, Nr 2-3, 2013, p 410-415 


\section{H Garnett \& C Murray}

\section{METHODS}

\section{Processing of Molecular Sieve Cartridges}

Figure 1 illustrates the vacuum rig used to process MSCs. High-purity $\mathrm{N}_{2}$ gas $(150 \mathrm{~mL} / \mathrm{min})$ is introduced to the MSC via a coupling (Colder Products Company, USA). The MSC (containing Type 13X zeolite molecular sieve [BDH, UK] and identical to the design used by Hardie et al. 2005) is placed within a tube furnace (Carbolite, UK) that is initially at room temperature, then heated to $500{ }^{\circ} \mathrm{C}$ to release the trapped $\mathrm{CO}_{2}$. Purge gas exiting the MSC enters the vacuum rig where it is first dried using a slush trap (mixture of dry ice and methylated spirits; $-78^{\circ} \mathrm{C}$ ) and then directed to an infrared gas analyzer (IRGA; PPSystems EGM-4, Hitchin, UK) where the $\mathrm{CO}_{2}$ concentration is measured. Next, the purge gas passes through 2 liquid nitrogen-cooled traps $\left(-196^{\circ} \mathrm{C}\right)$, retaining the $\mathrm{CO}_{2}$ and directing non-condensable gases to atmosphere (via a flow gauge). Once the majority of $\mathrm{CO}_{2}$ has been desorbed from the MSC (when the IRGA readout is $<10 \mathrm{ppm}$ ), collection of $\mathrm{CO}_{2}$ in the liquid nitrogen traps is stopped by isolating the traps from the MSC. A vacuum pump is then used to remove non-condensibles from the liquid nitrogen traps, and sample $\mathrm{CO}_{2}$ is dried for a second time by replacing the second liquid nitrogen trap with a slush trap, and the gas transferred to a calibrated volume to quantify the volume of $\mathrm{CO}_{2}$ recovered. At the same time as the recovered sample $\mathrm{CO}_{2}$ is being processed, purge gas continues to flow through the MSC via the IRGA to atmosphere, in order to ensure complete removal of $\mathrm{CO}_{2}$ from the cartridge (indicated when $\mathrm{CO}_{2}$ concentration of the purge gas reaches $0 \mathrm{ppm}$ ).

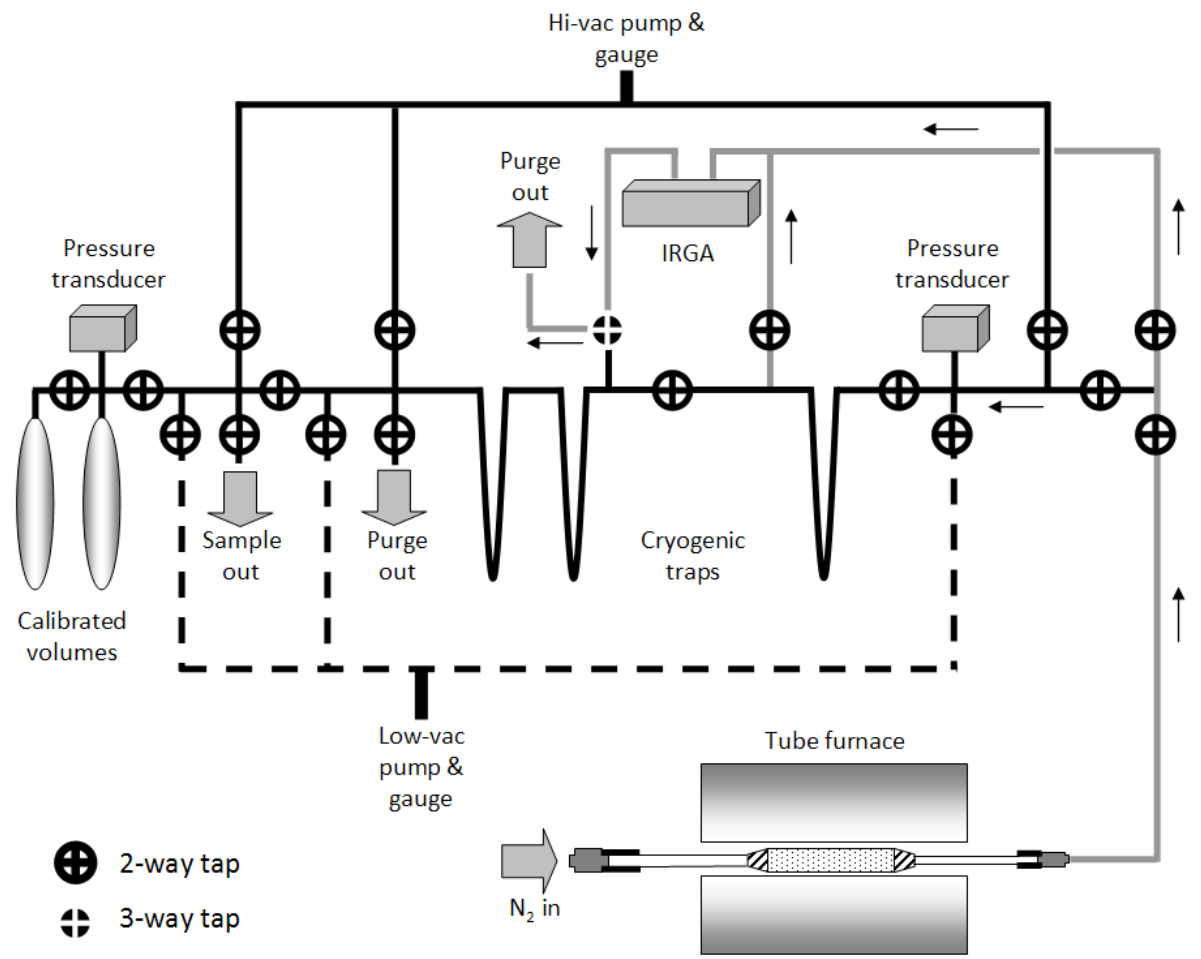

Figure 1 Design of the vacuum rig used to process molecular sieve samples by purging with nitrogen gas. A molecular sieve cartridge is shown within the tube furnace. An infrared gas analyzer (IRGA) is used to monitor $\mathrm{CO}_{2}$ concentration in the purge gas. Small arrows indicate the direction of the purge gas. See Methods for further details. 


\section{Test of Laboratory Methods}

Tests were performed to verify the new procedure, and especially check for sample carryover (memory effects) since the cartridges had previously been shown not to be affected by fractionation effects (Hardie et al. 2005). A suite of standards (Table 1) of distinctly different ${ }^{14} \mathrm{C}$ and stable-carbon isotope composition were sampled consecutively on $2 \mathrm{MSCs}$, and processed with the new procedures.

Table 1 Results for standards used to test the new procedures. Two molecular sieve cartridges (MSC; labeled 1 and 2) were used to consecutively sample $\mathrm{CO}_{2}$ derived from known-age or background standards, after initially being used to sample atmospheric $\mathrm{CO}_{2}$ (assumed to be $\sim 104 \mathrm{pMC}$ ). Consensus values for standards reported by Gulliksen and Scott (1995) and Boaretto et al. (2002) .

\begin{tabular}{|c|c|c|c|c|c|c|c|c|}
\hline $\begin{array}{l}\text { MSC- } \\
\text { Run } \\
\text { order }\end{array}$ & $\begin{array}{l}\text { Source of } \\
\mathrm{CO}_{2}\end{array}$ & $\begin{array}{l}\text { Volume } \\
\mathrm{CO}_{2} \text { re } \\
\text { covered } \\
(\mathrm{mL})\end{array}$ & $\begin{array}{l}\text { Reco- } \\
\text { very } \\
(\%)\end{array}$ & $\begin{array}{l}{ }^{13} \mathrm{C}_{\mathrm{VPDB}} \\
\text { standard } \\
\mathrm{CO}_{2} \\
\pm 0.1 \%\end{array}$ & $\begin{array}{l}{ }^{13} \mathrm{C}_{\mathrm{VPDB}} \\
\text { recovered } \\
\mathrm{CO}_{2} \\
\pm 0.1 \% \text { o }\end{array}$ & $\begin{array}{l}{ }^{14} \mathrm{C} \text { standard } \\
\mathrm{CO}_{2} \\
(\mathrm{pMC} \pm 1 \sigma)\end{array}$ & $\begin{array}{l}\text { Lab code } \\
\text { (SUERC-) }\end{array}$ & $\begin{array}{l}{ }^{14} \mathrm{C} \text { recovered } \\
\mathrm{CO}_{2} \\
(\mathrm{pMC} \pm 1 \sigma)\end{array}$ \\
\hline $1-1$ & Atmosphere & 5.8 & - & - & -9.9 & - & - & - \\
\hline $1-2$ & $\begin{array}{l}\text { Iceland spar } \\
\text { calcite }\end{array}$ & 8.9 & $>98$ & +1.6 & +1.4 & Background & 32517 & $0.34 \pm 0.01$ \\
\hline $1-3$ & $\begin{array}{l}\text { TIRI Barley } \\
\text { mash }\end{array}$ & 2.6 & $>99$ & -26.8 & -26.6 & $116.35 \pm 0.0084^{\mathrm{a}}$ & 32521 & $116.79 \pm 0.54$ \\
\hline $1-4$ & $\begin{array}{l}\text { FIRI Belfast } \\
\text { cellulose }\end{array}$ & 2.9 & $>95$ & -23.6 & -23.9 & $57.22 \pm 0.04^{\mathrm{b}}$ & 32523 & $57.08 \pm 0.25$ \\
\hline $2-1$ & Atmosphere & 6.1 & - & - & -10.1 & - & - & - \\
\hline $2-2$ & $\begin{array}{l}\text { TIRI Barley } \\
\text { mash }\end{array}$ & 9.0 & $>98$ & -26.8 & -27.0 & $116.35 \pm 0.0084^{\mathrm{a}}$ & 32518 & $116.85 \pm 0.54$ \\
\hline $2-3$ & $\begin{array}{l}\text { Iceland spar } \\
\text { calcite }\end{array}$ & 3.1 & 100 & +2.7 & +2.2 & Background & 32522 & $0.40 \pm 0.01$ \\
\hline $2-4$ & $\begin{array}{l}\text { FIRI Belfast } \\
\text { cellulose }\end{array}$ & 2.6 & $>97$ & -23.6 & -23.8 & $57.22 \pm 0.04^{\mathrm{b}}$ & 32516 & $57.62 \pm 0.26$ \\
\hline
\end{tabular}

Standard gases had been initially prepared to $\mathrm{CO}_{2}$ using routine laboratory procedures (combustion/ hydrolysis) and stored in sealed glass tubes. To collect each of the standard gases on a MSC, the glass tube containing the standard $\mathrm{CO}_{2}$ was placed in a 1-L air-tight chamber ("Kilner" jar; John Lewis, UK). This chamber was connected to the molecular sieve sampling system described by Hardie et al. (2005) using couplings (Colder Products Company, USA). Atmospheric $\mathrm{CO}_{2}$ was first removed from the chamber by scrubbing with soda-lime, and then the standard $\mathrm{CO}_{2}$ released by breaking the glass tube against the side of the chamber. An air pump (Pulse Pump III, MiDan Co., Chino, California, USA; flow rate $\sim 500 \mathrm{cc} / \mathrm{min}$ ) was used to circulate chamber air in a closed-loop via a MSC, enabling trapping of the standard $\mathrm{CO}_{2}$. The $\mathrm{CO}_{2}$ trapped on the molecular sieve was then recovered using the new procedures, the MSC recharged and reused for collecting the next standard.

Aliquots of the recovered $\mathrm{CO}_{2}$ were analyzed for $\delta^{13} \mathrm{C}$ and ${ }^{14} \mathrm{C}$ concentration. $\delta^{13} \mathrm{C}$ was determined on a dual-inlet isotope ratio mass spectrometer (VG Optima, UK) at the NERC Radiocarbon Facility and expressed in per mil relative to the Vienna-PDB reference standard. An aliquot of the recovered $\mathrm{CO}_{2}$ was converted to graphite using Fe-Zn reduction (Slota et al. 1987) and passed to the Scottish Universities Environmental Research Centre (SUERC) AMS Laboratory for ${ }^{14} \mathrm{C}$ measurement. ${ }^{14} \mathrm{C}$ results were normalized to a $\delta^{13} \mathrm{C}$ of $-25 \%$ and expressed as pMC following convention (Stuiver and Polach 1977). 


\section{H Garnett \& C Murray}

\section{RESULTS}

Measurements of the $\mathrm{CO}_{2}$ concentration in the purge gas taken by the IRGA show that $\mathrm{CO}_{2}$ was rapidly released from the molecular sieve when heated (Figure 2). In fact, it was observed that in some cases within the few minutes that it took for the furnace to reach the target temperature of $500{ }^{\circ} \mathrm{C}$, the $\mathrm{CO}_{2}$ concentration in the purge gas had already started to decline, indicating that the majority of the $\mathrm{CO}_{2}$ had been released at a slightly lower temperature. $\mathrm{CO}_{2}$ concentration fell to $0 \mathrm{ppm}$ (and therefore the MSC recharged for next use) in all samples within less than $\sim 40 \mathrm{~min}$ from the commencement of heating the sieve.

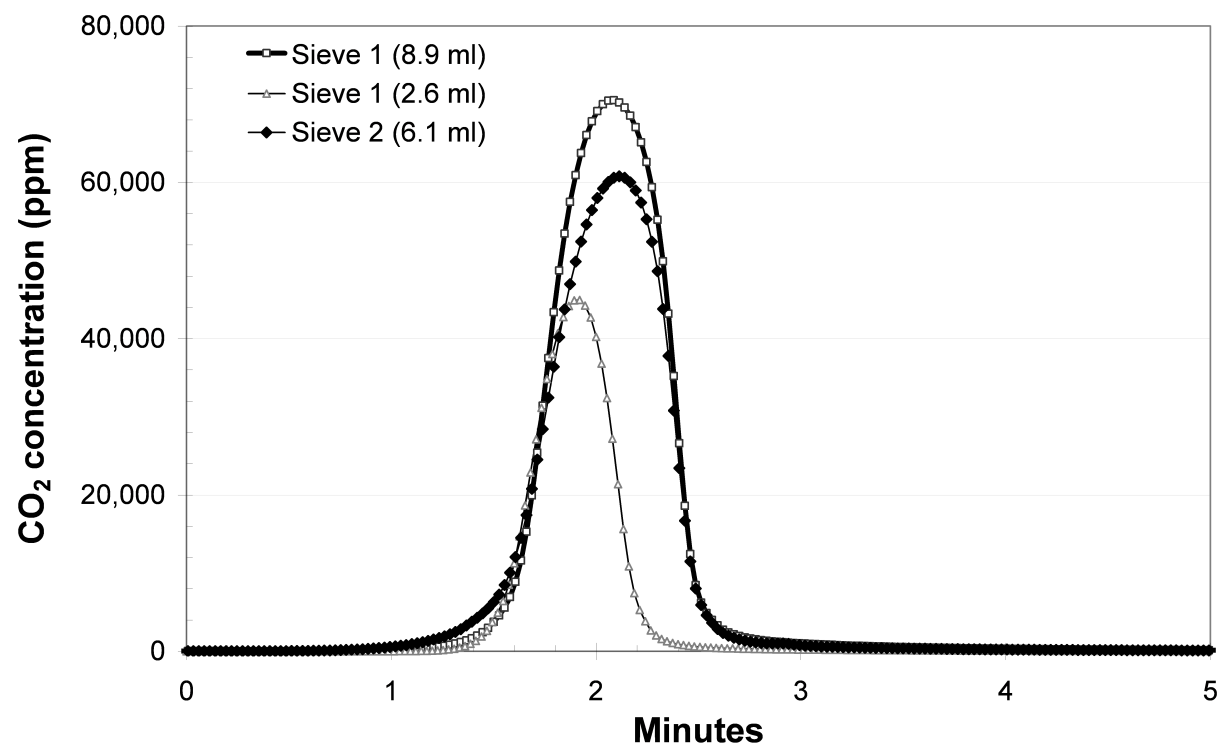

Figure 2 Carbon dioxide concentration of the purge gas when heated to release the sample (for standards 1-2, $1-3$, and 2-1). Heating of the sieve (starting at room temperature) began at $\sim 0 \mathrm{~min}$. The figure shows that the vast majority ( $>99 \%)$ of sample $\mathrm{CO}_{2}$ is desorbed from the sieve within 4 min.

The volume of $\mathrm{CO}_{2}$ recovered from the MSCs processed with the new methods was $95-100 \%$ of that expected based on the volume of the standard gas used (Table 1). In all cases, the ${ }^{14} \mathrm{C}$ concentration of the recovered $\mathrm{CO}_{2}$ was within measurement uncertainty $(2 \sigma)$ of the reference values for known-age standards (Table 1). Background $\left({ }^{14} \mathrm{C}\right.$-dead) standards had ${ }^{14} \mathrm{C}$ contents $(0.34 \pm 0.01$ and $0.40 \pm 0.01 \mathrm{pMC}$ ) only slightly higher than the laboratory background for combusted samples, and were considerably lower than background standards processed using the previous molecular sieve procedure (Hardie et al. 2005). All $\delta^{13} \mathrm{C}$ values were within measurement uncertainty $(2 \sigma)$ with the exception of 1 result (sample 2-3, which was just $>2 \sigma$ ).

\section{DISCUSSION}

Several studies have previously demonstrated the reliability of zeolite molecular sieve for trapping and purifying $\mathrm{CO}_{2}$ in samples for ${ }^{14} \mathrm{C}$ analysis. Some of these studies applied heat and vacuum to recover the sample $\mathrm{CO}_{2}$, although Wacker et al. (2010) showed that purging with helium efficiently removed adsorbed $\mathrm{CO}_{2}$ (using $\mathrm{N}_{2}$ as the purge gas could result in the condensation of $\mathrm{N}_{2}$ in liquid nitrogen traps [Bauer et al. 1992], but this is not something that we have observed using our method). When incorporated within a vacuum rig system, Bauer et al. (1992) successfully demon- 


\section{Processing $\mathrm{CO}_{2}$ Samples Collected Using Zeolite Molecular Sieve}

strated the use of a purge gas approach for processing ${ }^{14} \mathrm{C}$ samples with molecular sieve, as an alternative to cryogenic trapping with liquid nitrogen.

The vacuum and heating procedure previously used at the NERC Radiocarbon Facility for processing our field-collected samples had been shown to be reliable for samples of $\sim 10 \mathrm{~mL} \mathrm{CO}_{2}$ through testing with a suite of ${ }^{14} \mathrm{C}$ and stable-carbon isotope standards. We used a similar testing approach, but with smaller volumes $(2.6-9.0 \mathrm{~mL})$ to test the new procedures. It should be noted that the cartridges and sampling system used to trap the $\mathrm{CO}_{2}$ were almost identical to those used by Hardie et al. (2005); therefore, essentially it was only the new procedures that were being tested.

The results in Table 1 show that the new procedures are reliable for the processing of $\mathrm{CO}_{2}$ samples collected using MSCs and do not result in significant memory effects, contamination, or isotopic fractionation. Despite consecutively processing samples of distinctly different ${ }^{14} \mathrm{C}$ concentration on the same MSC, the ${ }^{14} \mathrm{C}$ results remained within measurement uncertainty $(<2 \sigma)$ of consensus values. The ${ }^{14} \mathrm{C}$ concentration of background standards $(0.34 \pm 0.01$ and $0.40 \pm 0.01 \mathrm{pMC})$ was only slightly higher than the background associated with routine combustion methods at the laboratory. The results for background standards were also considerably lower than when using the previous method $(1.23 \pm 0.02$ and $1.28 \pm 0.02 \mathrm{pMC}$; Hardie et al. 2005) despite the much smaller size of most of the samples processed using the new procedures. The fact that sample recovery for each of the $\mathrm{CO}_{2}$ standards was almost $100 \%$ further demonstrates the reliability of the new procedures, indicating that no significant quantities of $\mathrm{CO}_{2}$ remained on the molecular sieve following charging.

The results for test standards demonstrate the reliability of the new procedures, and while we consider that there is still potential for further improvement and refinement (e.g. further reduction in background and/or sample size), the new procedures bring significant benefits. Firstly, the time to process a sample using the new procedures is less than $\sim 40 \mathrm{~min}$, compared with the $\sim 2.5 \mathrm{hr}$ typically required to process a single sample using the previous method. Part of the saving in time is a result of being able to complete the recharging of the MSC at the same time as the recovered sample is still being processed (e.g. aliquoted). However, the greatest saving in time is a result of the rapidity that $\mathrm{CO}_{2}$ is desorbed from the molecular sieve when purged (Figure 2). Secondly, the new procedures enable the minimum sample size to be processed to be considerably reduced; results from our tests indicate that the new method is reliable for samples with as little as $2.6 \mathrm{~mL}$ of $\mathrm{CO}_{2}$ (compared with the recommended 5-10 $\mathrm{mL}$ of $\mathrm{CO}_{2}$ associated with the earlier method). Finally, incorporation of an IRGA into the purge gas stream allows for a much greater control when processing samples, for example, reliably informing when the molecular sieve has been completely desorbed of sample $\mathrm{CO}_{2}$.

\section{ACKNOWLEDGMENTS}

We thank staff at the NERC Radiocarbon Facility (East Kilbride) and SUERC AMS Laboratory. The UK Natural Environment Research Council (NERC) is gratefully acknowledged for facility support.

\section{REFERENCES}

Bauer JE, Williams PM, Druffel ERM. 1992. Recovery of submilligram quantities of carbon dioxide from gas streams by molecular sieve for subsequent determination of isotopic $\left({ }^{13} \mathrm{C}\right.$ and $\left.{ }^{14} \mathrm{C}\right)$ natural abundances. $\mathrm{An}$ alytical Chemistry 64:824-7.

Billett MF, Garnett MH, Hardie SML. 2006. A direct method to measure ${ }^{14} \mathrm{CO}_{2}$ lost by evasion from surface waters. Radiocarbon 48(1):61-8.
Billett MF, Dinsmore KJ, Smart RP, Garnett MH, Holden J, Chapman P, Baird AJ, Grayson R, Stott AW. 2012. Variable source and age of different forms of carbon released from natural peatland pipes. Journal of Geophysical Research 117:G02003, doi:02010.01029/ 02011JG001807.

Boaretto E, Bryant C, Carmi I, Cook G, Gulliksen S, Harkness D, Heinemeier J, McClure J, McGee E, 


\section{H Garnett \& C Murray}

Naysmith P, Possnert G, Scott M, van der Plicht H, Van Strydonck M. 2002. Summary findings of the fourth international radiocarbon intercomparison (FIRI) (1998-2001). Journal of Quaternary Science 17(7): 633-7.

Bol RA, Harkness DD. 1995. The use of zeolite molecular sieves for trapping low concentrations of $\mathrm{CO}_{2}$ from environmental atmospheres. Radiocarbon 37(2):64347.

Garnett MH, Hardie SML. 2009. Isotope $\left({ }^{14} \mathrm{C}\right.$ and $\left.{ }^{13} \mathrm{C}\right)$ analysis of deep peat $\mathrm{CO}_{2}$ using a passive sampling technique. Soil Biology and Biochemistry 41(12): 2477-83.

Garnett MH, Hartley IP. 2010. A passive sampling method for radiocarbon analysis of atmospheric $\mathrm{CO}_{2}$ using molecular sieve. Atmospheric Environment 44(7):877-83.

Garnett MH, Hartley IP, Hopkins DW, Sommerkorn M, Wookey PA. 2009. A passive sampling method for radiocarbon analysis of soil respiration using molecular sieve. Soil Biology and Biochemistry 41(7):1450-6.

Godwin H, Willis EH. 1964. Cambridge University natural radiocarbon measurements VI. Radiocarbon 6 : $116-37$.

Gulliksen S, Scott M. 1995. Report of the TIRI work- shop, Saturday 13 August 1994. Radiocarbon 37(2): $820-1$.

Hardie SML, Garnett MH, Fallick AE, Rowland AP, Ostle NJ. 2005. Carbon dioxide capture using a zeolite molecular sieve sampling system for isotopic studies $\left({ }^{13} \mathrm{C}\right.$ and $\left.{ }^{14} \mathrm{C}\right)$ of respiration. Radiocarbon $47(3): 441-$ 51.

Hardie SML, Garnett MH, Fallick AE, Ostle NJ, Rowland AP. 2009. Bomb- ${ }^{14} \mathrm{C}$ analysis of ecosystem respiration reveals that peatland vegetation facilitates release of old carbon. Geoderma 153(3-4):393-401.

Hartley IP, Garnett MH, Sommerkorn M, Hopkins DW, Fletcher BJ, Sloan VL, Phoenix GK, Wookey PA. 2012. A potential loss of carbon associated with greater plant growth in the European Arctic. Nature Climate Change 2:875-9.

Slota Jr PJ, Jull AJT, Linick TW, Toolin LJ. 1987. Preparation of small samples for ${ }^{14} \mathrm{C}$ accelerator targets by catalytic reduction of CO. Radiocarbon 29(2):303-6.

Stuiver M, Polach HA. 1977. Discussion: reporting of ${ }^{14} \mathrm{C}$ data. Radiocarbon 19(3):355-63.

Wacker L, Nemec M, Bourquin J. 2010. A revolutionary graphitisation system: fully automated, compact and simple. Nuclear Instruments and Methods in Physics Research B 268(7-8):931-4. 